\title{
Comparison of microscopy and PCR in detection of Mycobacterium tuberculosis
}

\author{
Pooja Saxena, Ashish K. Asthana, Molly Madan \\ Department of Microbiology, Subharti Medical College, Swami Vivekananda Subharti University, Meerut, U.P., India
}

\begin{abstract}
Objective: Tuberculosis (TB) one of the most important major causes of mortality and morbidity around the world. Early detection of TB affords to prevent transmission of TB and better treatment options. The aim of this study is to evaluate sensitivity of fluorescent, Ziehl Neelsen microscopy and Polymerase Chain Reaction (PCR) method.

Methods: Fifty samples of clinically suspected cases of pulmonary tuberculosis were collected and processed for Mycobacteria by Fluorescent and ZN staining. Negative samples by staining methods were processed by PCR method using primer IS6110 of M. tuberculosis complex.
\end{abstract}

Results: In total, 33/50 (66.0\%) samples were positive by Fluorescent and 23/50 (46\%) were positive by ZN method. All microscopically negative samples $(n=17)$ were processed to PCR and only seven of samples $(41.1 \%)$ showed positive results.

Conclusion: We concluded that PCR is best but it required lot of investment. J Microbiol Infect Dis 2014; 4(4): 141-144

Key words: Mycobacterium tuberculosis, PCR, fluorescent, Ziehl Neelsen, microscopy, detection

\section{Mycobacterium tuberculosis tanısında mikroskopi ve PCR metotlarının karşılaştırılması}

\section{ÖZET}

Giriș: Tüberküloz dünyanın her yerinde hala önemli bir mortalite ve morbidite nedenidir. TB'nin erken tanınması daha iyi tedavi sonuçları ve MDR-TB'nin daha az bulaşmasını sağlar. Bu çalışmanın amacı flöresan boyama, Ziehl-Neelson mikroskobi ve PCR metotlarının duyarlııı̆ını araştırmaktır.

Yöntemler: Klinik olarak akciğer tüberküloz şüphesi olan vakalardan 50 örnek toplandı ve mikobakteriler için floresan ve ZN boyalarla değerlendirildi. Boyama metotları ile negatif olan örnekler M. tuberculosis complex IS6110 primeri kullanılarak PCR metodu ile değerlendirildi.

Bulgular: Elli örnekten 33'ü $(\% 66,0)$ floresan ile ve 23'ü $(\%$ 46,0) ZN ile pozitifti. Mikroskobik olarak negative olan bütün örnekler ( $n=17)$ PCR ile çalışıldı ve sadece yedi örnek $(\% 41,1)$ pozitif bulundu.

Sonuç: PCR en iyi metot olarak görülmektedir ancak ciddi altyapı yatırımı gerektirmektedir.

Anahtar kelimeler: Mycobacterium tuberculosis, PCR, floresan, Ziehl Neelsen, mikroskopi, tespit

\section{INTRODUCTION}

Tuberculosis is an infectious disease caused by the Mycobacterium tuberculosis, primarily affects the lungs but can affects other body sites as well referred as extra pulmonary tuberculosis. ${ }^{1}$ Tuberculosis remains one of the most deadly and disabling, disease in the developing world. According to the World Health organization it was the eight highest cause of death and the tenth highest cause of disability. As known, the burden of tuberculosis is high- est in Africa and Asia. Almost $40 \%$ of the world's tuberculosis cases are living India and China. ${ }^{2}$ Control of TB in India has series problems including poor primary health-care infrastructure in rural areas. Beside this factor, use of first-line and second-line anti-TB drugs is not limited in the private health care sector. This situation contributes TB drug resistance.

World Health Organization launched the "Stop TB" strategy to give a vision to eliminate TB. This 
strategy aimed to start a global approach to eliminate this public health problem from the face of this earth by $2050 .^{3}$ In 2009 , the estimated global annual incidence was estimated as 9.4 million TB cases. On the other hand, two millions cases were estimated to have occurred in India. Indian cases approximately contribute to a fifth of the global burden of TB cases. Studies showed that $40 \%$ of Indian population is infected with TB bacillus. ${ }^{4}$

Thus, early detection of TB is an important tool for eradication of disease. Our study is based on comparison of different methods for diagnosis of TB.

\section{METHODS}

The study was conducted in the Department of Microbiology and Central Research Station, Subharti Medical College and Chhatrapati Shivaji Subharti hospital, Meerut. A total number of 50 respiratory samples were tested from patient attending from TB chest OPD. Patients of all ages and both genders were included. Samples (expectorated sputum, bronchioscopic aspiration, gastric lavages) were collected in sterile, leak proof, wide mouthed containers and labeled properly. From each patient three consecutive mornings samples were collected. The total span of study was conducted from February to July 2013. Samples were analyzed by Fluorescent and Ziehl Neelsen methods.

Fluorescent staining. Auramine $\mathrm{O}$ was used as fluorescent dye and examined under 40x. The bacilli are seen as bright rods against dark background (Figure 1). Unbound dye is removed by the acid-alcohol decolorizer solution. Potassium permanganate serves as a counter stain to suppress non-specific background fluorescence.

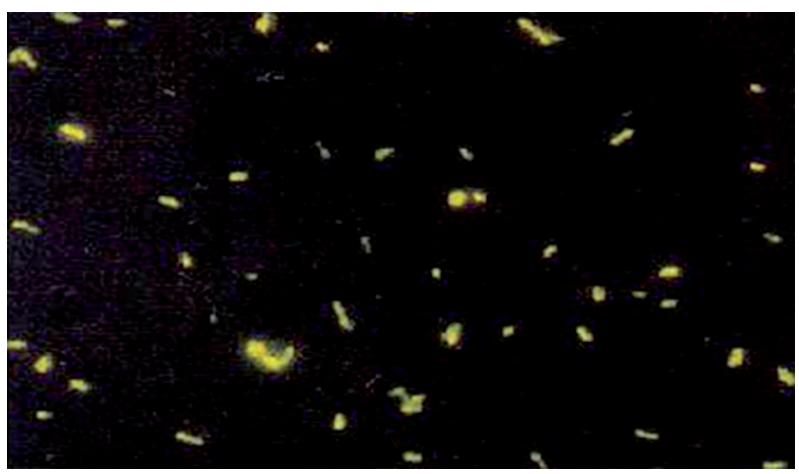

Figure 1. Mycobacterium tuberculosis appeared as bright rods against dark background
Acid-fast staining. Smears were prepared using the dissolved sediment from all specimens, stained by $\mathrm{ZN}$ method, and examined for presence of AFB (Figure 2). Smears recorded as per RNTCP guideline.

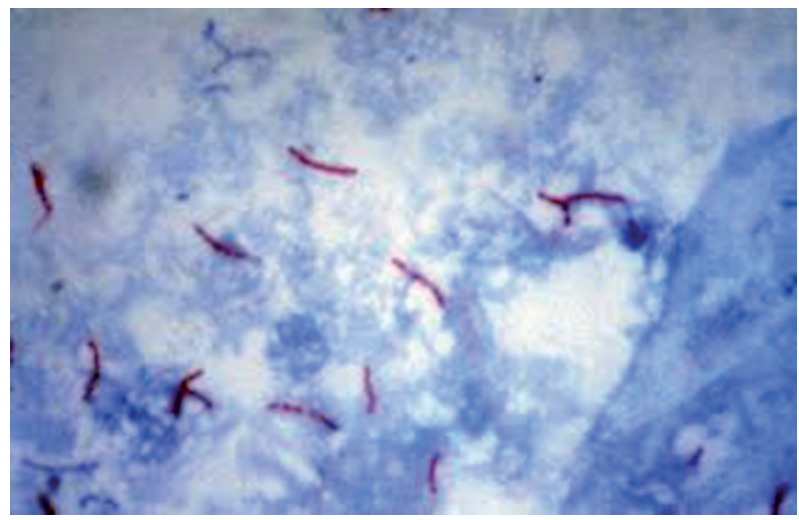

Figure 2. Mycobacterium tuberculosis appeared red against blue background

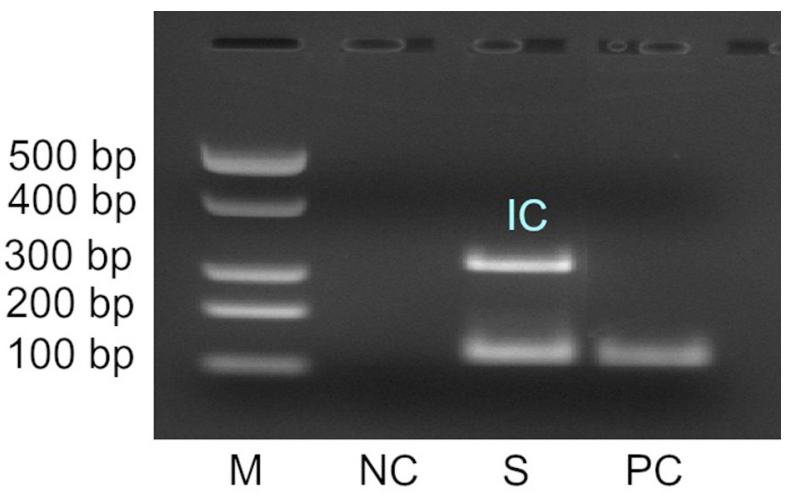

Figure 3. Amplified product of M. tuberculosis by PCR.

$\mathrm{NC}=$ Negative Control, $\mathrm{PC}=$ Positive Control, $\mathrm{IC}=$ Internal Control for Mycobacteria sp., as per kit manufacturers protocol (350 bp), Bp=Base Pair

Polymerase chain reaction (PCR). After decontamination and concentration, Extraction of DNA was done as per manufacturer's protocol (Bangalore Genei, Bangalore, India). PCR amplification was done in thermal cycler (Lab India Life Science) by specific primers IS6110. Positive and negative controls were also be run along with the samples. The amplified product was analyzed by electrophoresis at $123 \mathrm{bp}$ under UV light and photographed after $2.5 \%$ agarose gel electrophoresis by Ethidium bromide staining. The bands in the gel was photographed under Gel-Documentation system (Genei). An internal control band also visulised at $350 \mathrm{bp}$ in 
Mycobacterium species as per kit manufacturers guidelines( Banglore Genei, India), which was not visulised in other bacteria.

For IS6110 gene:

Primer 1: 5'- CCT GCG AGC GTA GGC GTC GG-3'

Primer 2: 5'- CTC GTC CAG CGC CGC TTG GG-3'

\section{RESULT}

Results are summerised in the form of table. Table1 showed positive samples by different staining methods. In $10-20$ and 31-40 years age groups, $50 \%$ samples were missed by By ZN method. While $61-70$ age group around $17 \%$ ware missed by $\mathrm{ZN}$ methods. In total only $46 \%$ samples were positive, while $64 \%$ positivity was reported by Fluorescent method. All staining negative samples (17) were tested by PCR, only seven samples were positive. Table 2 showed microscopy negative samples $(n=17)$, which was positive $41.1 \%$ by PCR.

Table 1. Number of samples positive by different staining methods

\begin{tabular}{lcc}
\hline Age (Years) & Fluroscent, $(\mathrm{n}=50)$ & ZN staining, $(\mathrm{n}=50)$ \\
\hline $10-20$ & 2 & 1 \\
$21-30$ & 6 & 5 \\
$31-40$ & 4 & 2 \\
$41-50$ & 7 & 4 \\
$51-60$ & 3 & 2 \\
$61-70$ & 5 & 4 \\
$71-80$ & 6 & 5 \\
\hline Total & 33 & 23 \\
\hline
\end{tabular}

Table 2. Microscopy negative samples $(n=17)$ analysed by PCR

\begin{tabular}{rc}
\hline Age (Years) & PCR positive samples \\
\hline $10-20$ & 0 \\
$21-30$ & 1 \\
$31-40$ & 2 \\
$41-50$ & 0 \\
$51-60$ & 0 \\
$61-70$ & 1 \\
$71-80$ & 3 \\
\hline TOTAL & 7 \\
\hline
\end{tabular}

\section{DISCUSSION}

Fluorescent staining showed $66 \%$ positive while by ZN staining procedure $46 \%$. Our result correlated with the study done by Kocagoz et al. 1993 and Saroj et al. 2011..$^{5-7}$ in which the authors reported that fluorescent microscopy is better than $\mathrm{ZN}$ method. All microcsopy negative samples (17) were further tested by PCR method Target genes IS6110. Only 7/17 (41.1\%) microscopy missed samples were positive by PCR method. Therefore, PCR can detect Mycobacterium tuberculosis more efficiently, which were missed by microscopy. ${ }^{8}$ On the basis of our PCR results we can confirm that IS6110-based PCR methodology for M. tuberculosis can be highly specific and sensitive for detecting TB from variety of clinical specimens, which were usually missed by microscopy.

Patient from 10 to 80 years of age were included in this study. Twenty percent of samples were missed by ZN staining, which were positive in fluorescent staining. Nearly half of staining negative samples was found positive by PCR. Therefore, study shows that PCR is better but false positive results may also be possible. Therefore clinical correlation is recommended. Although PCR is best for low grade bacterimia but it is required lot of investment, Fluorescent microscopy also required lot of investment. So in remote areas ZN stain is recommended. Previous studies showed that fluorescence microscopy ist at least $10 \%$ more sensitive than traditional light microscopy. ${ }^{9}$

In conclusion, that PCR method is best for detection of $M$. tuberculosis. Fluorescent method is better than $\mathrm{ZN}$ and $\mathrm{ZN}$ method does not required large investment and easy but detection limit is low. To avoid confusion in clinical decision, correlation of clinical compatibility is important.

\section{ACKNOWLDGEMENT}

This internship is the result of a month's work and observations whereby I have been accompanied and supported by many people. I would like to thanks Dr. A.K. Asthana, Principal, Subharti Medical College, Meerut who give me opportunity to work Medical College and Chaatrapati Shivaji Subharti Medical Hospital Meerut.

\section{REFERENCES}

1. Park K. Tuberculosis, In: Park's Textbook of Preventive and Social Medicine, 15th edition. Banarasidas Bhanot Publishers, 1997, 138-151. 
2. WHO Global Tuberculosis Report-2012. www.who.int/iris/bitstr eam/10665/75938/1/9789241564502_eng.pdf

3. Sandhu G K. Tuberculosis: Current Situation, Challenges and Overview of its Control Programs in India J Global Infect Dis 2011;3(2):143-150.

4. Sachdeva KS, Kumar A, Dewan P, et al. New version of Revised National Tuberculosis Control Program (RNTCP): Universal Access-"Reaching the Unreached". Ind J Med Res 2012;135:690-694.

5. Saroj H, Nita P, Malhotra B, et al. Comparison of Zeihl Neelsen and Auramine-O-Staining Methods on Direct and Concentration Smears in Clinical Specimens. Ind J Tuberculosis 2011;58(2):51-53.
6. Kocagoz T, Maz E, Ozkara E, et al. Detection of Mycobacterium tuberculosis in sputum samples by Polymerase Chain Reaction using a simplified procedure. J Clin Microbiol 1993;31(6):1435-1438.

7. Somoskovi A, Hotaling JE, Lessons from a proficiency testing event for acid fast microscopy. Chest 2001;120(1):250-257.

8. Kansal R, Agarwal C, Madan M, Asthana AK. Rapid diagnosis of extrapulmonary tuberculosis by nested polymerase chain reaction (nPCR) based on IS 6110 insertion sequence of $M y$ cobacterium tuberculosis. Asian J Microbiol, Biotech Env Sc 2013;15(3):517-520

9. Hendry C, Dionne K, Hedgepeth A, et al. Evaluation of a Rapid Fluorescent Staining Method for Detection of Mycobacteria in Clinical Specimens. J Clin Microbiol 2009; 47(4):12061208. 